\title{
The use of e-portfolios to support professional development of student nutritionists - a pilot study
}

\author{
J. Holmes and J. L. Murphy \\ School of Health and Social Care, Bournemouth University, BHI 3LT, UK
}

Portfolios are a useful approach to present and record evidence for the assessment of skills and competencies. ${ }^{(1)}$ The use of electronic portfolios has been advocated to support personal development planning (PDP) ${ }^{(2)}$ and their use has been shown to be multifunctional to link education and professional practice ${ }^{(3)}$ as well as for developmental purposes such as reflection, competency and skill management and presentation for assessment and professional registration. ${ }^{(4)}$ However little is known about the attitudes of undergraduate nutrition students to e-portfolios and PDP. The aim of this study was to establish if a voluntary e-portfolio would encourage students to reflect on their work and use as an electronic space to record evidence for professional registration after graduation.

The e-portfolio was introduced as a pilot in October 2009 to all interested BSc (Hons) Nutrition students at Bournemouth University. The university's virtual learning environment provided the space to create individual e-portfolios. An online learning tool supported the students and 6 weeks after the introduction a workshop was held to give IT support. A virtual discussion forum enabled users and staff to discuss and monitor issues. Students were invited to complete a short questionnaire encapsulating their experiences at the end of the academic year.

Fifty-two (79\%) students from a total programme cohort of sixty-six students initially signed up to use the e-portfolio. Ten students, from across the programme, completed the questionnaire and of these two, had created an e-portfolio. Common reasons given for not completing the e-portfolio were: I am in the first year of my studies and finishing my degree and registration seems a long-time away $(28.7 \%)$; I have had insufficient time $(71.4 \%)$; the university workload this year has been so great I have not wanted to complete extracurricular projects $(57.7 \%)$; the system is not transferable to the registration body $(42.8 \%)$. Nearly two-thirds of respondents felt they would be more motivated to use the e-portfolio if it was assessed. Opinion was equally split as to whether assessment should be across the whole programme or for specific units.

Despite initial interest, the very low level of engagement with the e-portfolio was disappointing. The findings indicate that assessment may be required to embed the use of e-portfolios in the undergraduate curriculum. Further work is required to evaluate the use of e-portfolios in the assessment process. Consideration needs to be given to a dedicated e-portfolio system as an integral part of both student training and continued professional development for the registered nutritionist.

1. Landman JP \& Wootton SA (2007) Professional regulation of nutritionists: Where are we now? Proc Nutr Soc 66, 269-276.

2. JISC. (2008) Effective practice with e-portfolios - supporting 21 st Century learning. Available at: http://www.jisc.ac.uk/media/documents/publications/ effectivepracticeeportfolios.pdf

3. Littlejohn A \& Higgison C (2003) E-learning series no 3 - A guide to teachers. Available at http://www.jiscinfonet.ac.uk/InfoKits/effective-use-ofVLEs/resources/ltsn-e-learning-guide-for-teachers

4. Madden T (2007) Suporting student e-portfolios. The Higher Education Academy - Physical Sciences Centre. Available at http://www.heacademy. ac.uk/assets/ps/documents/practice_guides/eportfolios_JISC.pdf 